\title{
Molecular detection of Epstein-Barr virus in breast cancer
}

\section{among Sudanese female population: a case-control study}

\section{[version 1; peer review: 2 not approved]}

\author{
Eiman S. Ahmed1', Lubna S. Elnour², Emmanuel E. Siddig (iD1,2, Rowa Hassan (D1,3 \\ ${ }^{1}$ Mycetoma Research Center, University of Khartoum, Khartoum, 11111, Sudan \\ ${ }^{2}$ Faculty of Medical Laboratory Sciences, University of Khartoum, Khartoum, 11111, Sudan \\ ${ }^{3}$ Global Health and Infection Department, Brighton and Sussex Medical School, Brighton, BN1 9PX, UK
}

\author{
V1 First published: 05 Aug 2019, 8:1355 \\ https://doi.org/10.12688/f1000research.19422.1 \\ Latest published: 05 Aug 2019, 8:1355 \\ https://doi.org/10.12688/f1000research.19422.1
}

\section{Abstract}

Background: Breast cancer is the most common cancer in women worldwide and in Sudan. Breast cancer occurs due to a multifactorial process and infection with an oncogenic virus has been recently investigated as a possible risk factor for breast cancer. For nearly two decades, studies have incriminated Epstein-Barr virus (EBV) in the etiology of breast cancer. However, the results are unconvincing, and their interpretation has remained a matter of debate. The aim of this study was to detect EBV in breast cancer biopsies obtained from Sudanese female patients.

Methods: A descriptive, hospital-based, case-control study, conducted at Faculty of Medical Laboratory Science, University of Khartoum, Khartoum, Sudan. Archival blocks were obtained from 115 patients with breast cancer and 115 controls during the period between November 2016 till March 2017.

Results: Among 115 breast cancer tissue specimens, EBV DNA was identified in 42/115 (36.5\%) samples and was not identified in 73/115 $(63.5 \%)$ tissue samples. The highest frequency of EBV detection was among 41-60 year-olds (23/42, 54.7\%), followed by 21-40 year-olds $(12 / 42,28.5 \%)$ and $61-80$ year-olds (5/42, $11.9 \%)$. In the control group, the majority were diagnosed with fibroadenoma (70.4\%), followed by fibrocystic changes (10.4\%) and lactating changes (0.9\%). Conclusion: The data obtained in this study demonstrated that EBV was present in a high percentage of our study population; however, the exact role of EBV in Sudanese breast cancer needs to be studied more in depth.

\section{Keywords}

Breast cancer, Invasive Ductal carcinoma, Epstein-Barr virus

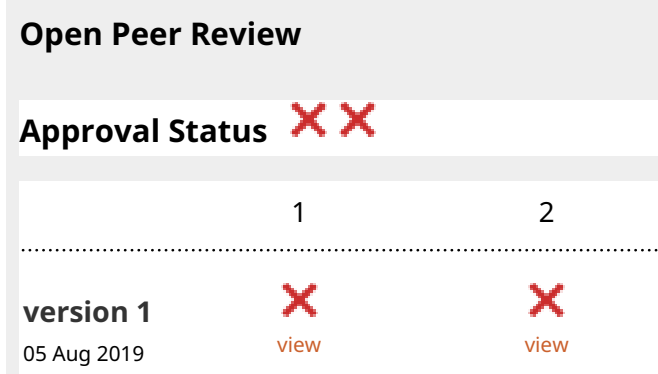

\section{Sulma Ibrahim Mohammed (iD), Purdue \\ University, West Lafayette, USA \\ 2. James Lawson, University of New South \\ Wales, Sydney, Australia}

Any reports and responses or comments on the article can be found at the end of the article. 
Corresponding author: Rowa Hassan (Roaalbasha2016@outlook.com)

Author roles: Ahmed ES: Conceptualization, Data Curation, Formal Analysis, Investigation, Resources, Writing - Original Draft Preparation, Writing - Review \& Editing; Elnour LS: Conceptualization, Data Curation, Investigation, Methodology, Software, Validation, Visualization, Writing - Original Draft Preparation, Writing - Review \& Editing; Siddig EE: Conceptualization, Data Curation, Funding Acquisition, Investigation, Methodology, Project Administration, Validation, Writing - Original Draft Preparation, Writing - Review \& Editing; Hassan R: Conceptualization, Data Curation, Formal Analysis, Funding Acquisition, Investigation, Methodology, Project Administration, Resources, Software, Supervision, Validation, Visualization, Writing - Original Draft Preparation, Writing - Review \& Editing

Competing interests: No competing interests were disclosed.

Grant information: The author(s) declared that no grants were involved in supporting this work.

Copyright: (c) 2019 Ahmed ES et al. This is an open access article distributed under the terms of the Creative Commons Attribution License, which permits unrestricted use, distribution, and reproduction in any medium, provided the original work is properly cited.

How to cite this article: Ahmed ES, Elnour LS, Siddig EE and Hassan R. Molecular detection of Epstein-Barr virus in breast cancer among Sudanese female population: a case-control study [version 1; peer review: 2 not approved] F1000Research 2019, 8:1355 https://doi.org/10.12688/f1000research.19422.1

First published: 05 Aug 2019, 8:1355 https://doi.org/10.12688/f1000research.19422.1 


\section{Abbreviations}

EBNA-4, Epstein-Barr virus nuclear antigen 4; EBV, EpsteinBarr virus; LMP1, latent membrane protein 1; MEC, mammary epithelial cell; PCR, polymerase chain reaction

\section{Introduction}

Epstein-Barr virus (EBV) was discovered in the early 1960s by direct electron microscopy and it infects up to $95 \%$ of the adult human population, primarily in their early life. It usually remains silent and doesn't cause any symptoms as the immune system doesn't treat the virus like an invader following the initial infection. However, infection can lead to severe manifestations in later life $\mathrm{e}^{1,2}$. This virus has been found to be the cause of many types of cancers including Burkitt's lymphoma, Hodgkin's disease, non-Hodgkin's lymphoma, nasopharyngeal carcinoma, as well as Leiomyosarcoma arising in immunocompromised individuals $\mathrm{s}^{3,4}$. The main mechanism by which the virus can induce cell transformation from normal to malignant cells is not yet understood and is still under investigation, although some researchers have related this to EBV viral protein effects ${ }^{5-8}$.

Breast cancer is one of the most frequent types of cancers and is the leading cause of death in females globally ${ }^{9}$. Several factors can promote the development of breast cancer, including infections, especially oncogenic viruses that have been proven to be possible risk factors for the development of the cancer. These viruses include mouse mammary tumour virus (MMTV, causes breast cancer in mice), EBV and human papilloma virus $(\mathrm{HPV})^{10-12}$. EBV DNA was identified previously in several studies using different molecular based techniques, including sequencing, polymerase chain reaction (PCR), in situ hybridization, immunohistochemistry and real-time PCR ${ }^{13}$.

In Sudan, breast cancer is a leading type of cancer in adults, along with leukemia, prostatic carcinoma, lymphoma and colorectal carcinoma ${ }^{14}$. Therefore, we aim in this study to detect EBV in breast cancer biopsies obtained from Sudanese female patients.

\section{Methods}

\section{Study design}

This is a descriptive, hospital-based, case-control study, conducted at Faculty of Medical Laboratory Science, University of Khartoum, Khartoum City, Sudan, during the period of November 2016 until March 2017.

\section{Sample collection}

Samples were collected from Soba Teaching Hospital and Military Hospital in Khartoum state, Sudan, during the period of November 2016 to January 2017. Archival blocks of 115 female patients diagnosed with breast cancer and 115 normal breast lesions (controls) were retrieved for the detection of EBV. All archival blocks from female patients diagnosed with breast cancer were included in the study, with no further inclusion or exclusion criteria. For the controls, archival blocks from women with a breast lesion, not diagnosed as breast cancer, taken during the same period as the breast cancer patient samples were included. The control samples were not matched to the breast cancer patient samples. Analysis of these blocks were carried out during the period of February 2017 to March 2017.
Preparation of formalin-fixed paraffin-embedded tissue

Formalin-fixed paraffin-embedded blocks (FFPB) were cut at a thickness of $10 \mu \mathrm{m}$ using a rotary microtome and the ribbons of the cut tissues transferred into $1.5 \mathrm{ml}$ eppendorf tube using sterile forceps. The samples were deparaffinized by adding $1 \mathrm{ml}$ of xylene to each sample and incubating for 30 minutes to allow the removal of the wax from the tissue sections. This step was repeated twice. The tissue was rehydrated using a series of ethanol washes, using 95\%, $80 \%$ and then $70 \%$ ethanol for $15 \mathrm{~min}$ for each.

\section{DNA extraction and assessment of DNA quality}

The DNA was extracted using the phenol-chloroform method with the aid of lysis buffer that composed from Sodium dodecyl sulfate (SDS) and proteinase $\mathrm{K}(40 \mu \mathrm{l})$ to get rid of proteins, as previously described ${ }^{15-17}$. To purify the DNA from the lysate, buffer saturated phenol was used. Then, in order to precipitate the DNA, 3M sodium acetate and isopropanol were added and this was spun in a centrifuge at $16000 \mathrm{rpm}$ for seven mins to pellet the nucleic acid. This step was followed by washing in $70 \%$ ethanol to get rid from the salts and centrifugation at high speed to reconstruct the pellet again.

DNA was resuspended in distilled water, quantified and stored at $-20{ }^{\circ} \mathrm{C}$. The final extracted DNA was checked for purity and quantity using a Nanodrop 1000 spectrophotometer. If the 260/280 $\mathrm{nm}$ absorption ratio was between $1.8-2$, the DNA was considered to be pure. Purified DNA was used for PCRs.

\section{Molecular identification of EBV}

To determine if the EBV DNA was present in our samples, DNA was amplified for detection of the EBV LMP-1 gene using forward 5- CCG AAG AGG TTG AAA ACA AA-3 and reverse 5- GTG GGG GTC GTC ATC ATC TC-3 primers. PCR was performed in a final reaction volume of $25 \mu$, with $1 \mu$ of template DNA, using iNtRON's Maxime PCR PreMix Kit (i-Taq, Korea; Catalog No. 25025) according to manufacturer instructions. The following PCR conditions were used: $4 \mathrm{~min}$ at $95^{\circ} \mathrm{C}$; then 35 cycles consisting of a denaturing step at $94^{\circ} \mathrm{C}$ for $1 \mathrm{~min}$, an annealing step at $60^{\circ} \mathrm{C}$ for $1 \mathrm{~min}$ and a polymerization step at $72^{\circ} \mathrm{C}$ for $1 \mathrm{~min}$; followed by a single incubation step for 10 min at $72^{\circ} \mathrm{C}$. PCR was performed on an Aeris Thermocycler (AERIS-BG096, Esco Micro Pte.Ltd, Singapore).

\section{Analysis of $\mathrm{PCR}$ results}

The amplification product of $131 \mathrm{bp}$ was separated on a $2 \%$ agarose gel stained with ethidium bromide and visualized under UV light using the UVCI-1100 gel imaging system (Major Science, UVCI-1100, Saratoga, CA, USA). A 100 bp DNA ladder was used and a band of $131 \mathrm{bp}$ was considered as a positive (Figure 1).

\section{Statistical analysis}

The statistical analysis was performed using SPSS (version 16.0) statistical software. Descriptive statistics were conducted to generate graphical and numerical summaries. The Chisquared test was used to compare the frequencies of the categorical variables. A value of $\mathrm{p}<0.05$ was considered statistically significant. 


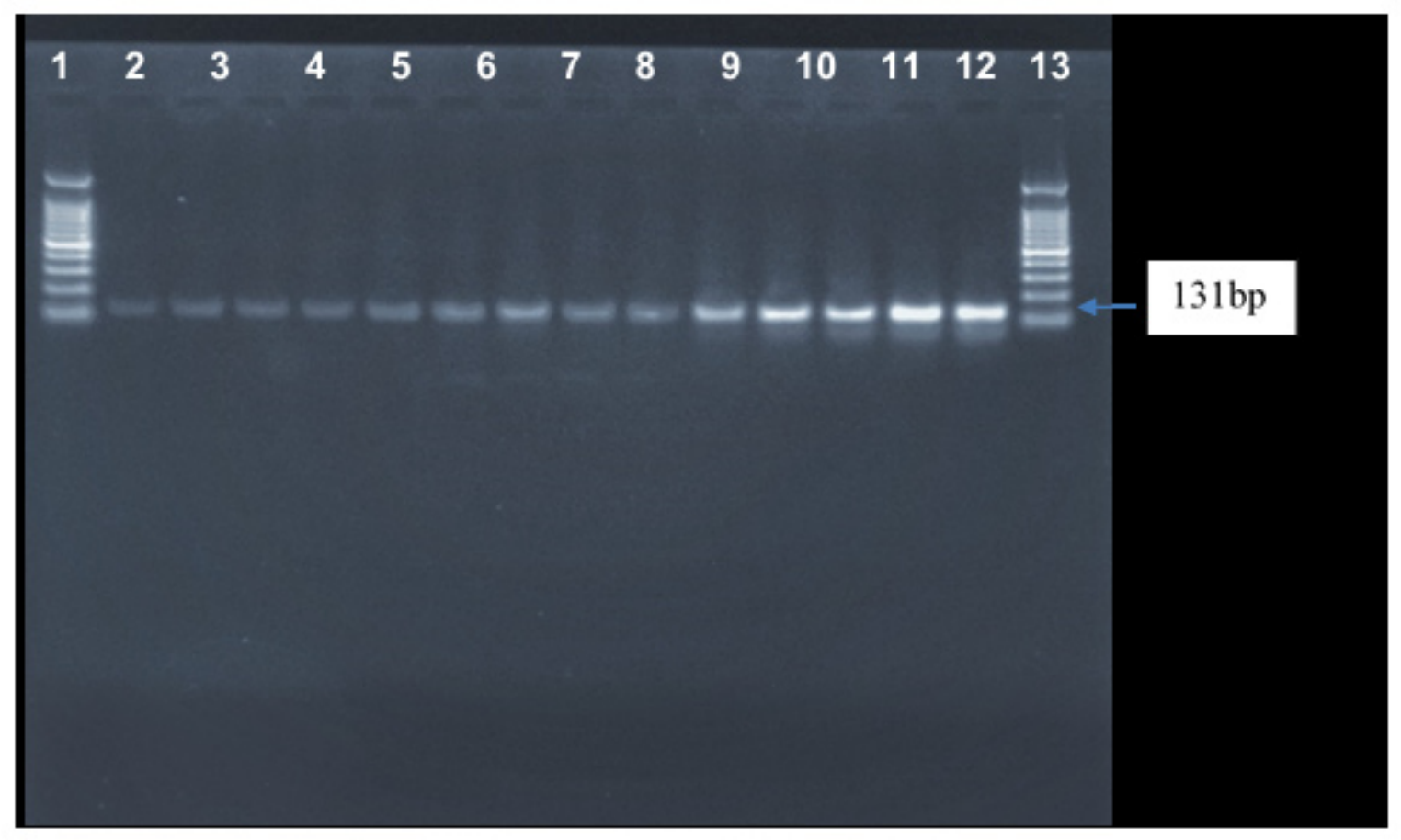

Figure 1. Gel electrophoresis of PCR products. PCR products were loaded on $2 \%$ agarose gel containing ethidium bromide and visualized under UV light. Lanes 1 and 13 show the 100bp DNA ladder. Lanes 2 - 12 show different samples containing the PCR product of 131 bp.

\section{Ethical statement}

The study was approved by the faculty research board of the faculty of Medical Laboratory Sciences, University of Khartoum, Sudan. Written informed consent was obtained from patients for the use of their samples and publication of results.

\section{Results}

The age of the breast cancer patients ranged between 23 and 80 years and the mean age was $50.49 \pm 9.50$ years, while the control group age ranged from 25 to 72 years and the mean age was $37.65 \pm 5.89$ years $^{18}$. Regarding histological type, $96(83.5 \%)$ of the patients diagnosed with breast cancer had invasive ductal carcinoma, 18 (15.7\%) had invasive lobular carcinoma and one $(0.9 \%)$ had mucinous carcinoma. Regarding the clinical staging (according to the TNM staging of the American Joint Committee on Cancer), 10 (8.7\%) were stage I, 13 (11.3\%) were stage IIA, $15(13 \%)$ were stage IIB, 17 (14.8) were stage IIIA, 24 $(20.9 \%)$ were stage IIIB and 36 (31.1) were stage IV (Table 1). In the control group, the majority were diagnosed with fibroadenoma (70.4\%), followed by fibrocystic changes (10.4\%) and lactating changes $(0.9 \%)$.

Among the 115 breast cancers tissue specimens, EBV DNA was identified in 42/115 (36.5\%) samples and was not identified in 73/115 $(63.5 \%)$ tissue samples (Table 2). In the control group, EBV was detected in 101/115 (87.8\%) and only 14/115 $(12.2 \%)$ tested negative for the presence of the virus. The Chisquare test showed that EBV has a significant effect on breast cancer with a p-value of 0.001 .
The highest frequency of infection was seen in the age group 41-60, with infection found in 23/42 (54.7 \%), followed by age ranges $21-40(12 / 42,28.5 \%)$ and $61-80(5 / 42,11.9 \%)$.

Notably, with regard to EBV infection and staging of breast cancer, by far the majority of infections were detected among stage IV $(11 / 42,26.1 \%)$, followed by stage IIIA (10/42, 23.8\%), and stage IIIB $(8 / 42,19.0 \%)$, although these results were shown to be statistically insignificant (Table 3 ).

\section{Discussion}

Breast cancer has been proven to be a leading cause of death amongst women in the western world after lung cancer. Its incidence has been confirmed to be higher in females than males, and the number of cases increase with age. Early case detection has improved due to the promotion of screening procedures and diagnosis ${ }^{19,20}$. In Sudan, breast cancer still accounts for many cases of cancer among women. In 1959, breast cancer was found to account $22.9 \%$ of all cancer cases. The bulk of those patients were females within the menopausal age, with disease clinically progressing in a similar pattern as in European ladies ${ }^{21,22}$. In 2010, an updated study of breast cancer prevalence in Sudan by Intisar and colleagues found a prevalence of 25.1 per $100,000^{23}$.

For approximately twenty years, studies have been conducted that have aimed to identify the association between EBV and breast cancer. The first report of an association between EBV and breast cancer was from a study that carried out screening of blood 
Table 1. The distribution of study population by age, histological type and staging.

\begin{tabular}{|c|c|}
\hline Characteristic & Percentages \\
\hline Age range & \\
\hline $21-40$ & $22(10.1 \%)$ \\
\hline $61-60$ & $77(67.0 \%)$ \\
\hline Histological subtypes & $16(13.9 \%)$ \\
\hline Invasive ductal carcinoma & $96(83.5 \%)$ \\
\hline Invasive lobular carcinoma & $18(15.7 \%)$ \\
\hline Mucinous carcinoma & $1(0.9 \%)$ \\
\hline Stage & \\
\hline Stage I & $10(8.7 \%)$ \\
\hline Stage II A & $13(11.3 \%)$ \\
\hline Stage II B & $15(13 \%)$ \\
\hline Stage III A & $17(14.8)$ \\
\hline Stage III B & $24(20.9 \%)$ \\
\hline Stage IV & $36(31.3 \%)$ \\
\hline
\end{tabular}

Table 2. The distribution of Epstein-Barr virus (EBV) among patient and control groups.

\begin{tabular}{|c|c|c|c|}
\hline & \multicolumn{2}{|c|}{ Controls } & Total \\
\hline Patients & Negative & Positive & \\
\hline Negative & 59 & 14 & 73 \\
\hline Positive & 42 & 0 & 42 \\
\hline Total & 101 & 14 & 115 \\
\hline
\end{tabular}

(Chi square test; $p$ value $=0.001$ )

Table 3. The distribution of the study population by staging and Epstein-Barr virus (EBV) infection.

\begin{tabular}{|l|c|c|c|}
\hline Staging & $\begin{array}{c}|c| \\
\text { Positive }\end{array}$ & \multicolumn{2}{|c|}{ Notal } \\
\hline Stage I & 2 & 8 & 10 \\
\hline Stage II A & 7 & 6 & 13 \\
\hline Stage II B & 4 & 11 & 15 \\
\hline Stage III A & 10 & 7 & 17 \\
\hline Stage III B & 8 & 16 & 24 \\
\hline Stage IV & 11 & 25 & 36 \\
\hline Total & 42 & 73 & 115 \\
\hline
\end{tabular}

(Chi square test; $p$ value $>0.05$ ) and DNA of 91 patients with breast cancer by PCR in order to detect the EBV genome in $1995^{24}$. Since that, other studies have confirmed the finding that EBV is associated with breast cancer $^{25-33}$. However, these results have been controversial since negative results were obtained in some studies and explanations of the results have been under discussion for several years ${ }^{25,34-38}$.

Moreover, in $2016 \mathrm{Hu}$ and colleagues queried whether the EBV can be associated with breast cancer development. NOD/ SCID mice were used and their results suggested that EBV can infect primary human mammary epithelial cells (MECs) through $\mathrm{CD} 21$, leading to phenotypic variations consistent with transformation. These immortalized MECs infected with EBV cooperatively (with activated Ras) increase tumor formation in vivo, recapitulating a multi-step tumorigenesis in an established animal model ${ }^{39}$.

A study was conducted in 2014 by Yahia and colleagues to study the relationship between breast cancer and the presence of EBV genome. Interestingly, this was the first study in Sudan to assess the role of EBV infection in the etiology of breast cancer. They used PCR and in situ hybridization to screen 92 breast cancer samples, aiming to measure the presence of Epstein-Barr nuclear antigen 4 (EBNA-4) and LMP-1. Their final outcome was statistically significant $(p=0.0001)$, demonstrating the presence of EBV genome in $49(53.3 \%)$ and $10(11 \%)$ patients by LMP1 and EBNA-4 PCR, respectively ${ }^{10}$. This result is in agreement with our results, which showed that EBV DNA was identified in $42 / 115(36.5 \%)$ samples and was not identified in $73 / 115$ $(63.5 \%)$ tissue samples.

Notably, the incidence of EBV among Iranian females with breast cancer has been found to be low compared to our findings. In 2016, Mohammad Izadeh and colleagues tested LMP-1 antigen expression in breast carcinoma using immunohistochemistry in 80 Iranian patients. LMP-1 expression was detected in 6 cases $(7.5 \%)$ of breast carcinoma cases and these results were found to be statistically significant. LMP-1 expression was not detected in the normal breast tissue, taken from a site adjacent to the carcinoma, in all cases ${ }^{40}$. Furthermore, another study from Iran, conducted by Kadivar and colleagues, to evaluate the presence of EBV in benign and malignant breast lesions using PCR and immunohistochemistry is also in disagreement with our results, as all breast cancer samples were negative for EBV, as were the control group samples ${ }^{41}$.

The present study verified the presence of EBV in $36.5 \%$ of the total breast cancer samples, in agreement with the study conducted by Bonet and colleagues, in which $51(51 \%)$ cases were found to be positive for EBV by PCR out of a total of 100 breast cancer cases $^{27}$.

However, this study has some limitations. The study did not use cohort techniques to assess whether EBV viral load had an effect on the prognosis of breast cancer and we could not use advanced techniques for visualization of the virus in the malignant cells due to time and budget constraints. 


\section{Conclusion}

In conclusion, the data obtained in this study demonstrated that EBV was present in a high percentage of our study population; however, the exact role of EBV in Sudanese breast cancer needs to be studied more in depth.

\section{Data availability}

\section{Underlying data}

Harvard Dataverse: Replication Data for: EBV and Breast cancer Data among Sudanese patients. https://doi.org/10.7910/DVN/ 94YOCV ${ }^{18}$

EBV_and_Breast_cancer_Data.tab (diagnoses, PCR results and ages of patients and controls)
Data are available under the terms of the Creative Commons Zero "No rights reserved" data waiver (CCO 1.0 Public domain dedication).

Grant information

The author(s) declared that no grants were involved in supporting this work

\section{Acknowledgements}

We would like to express our gratitude to Miss Abeer Musa for her indefatigable help and support.
1. Andrei G, Trompet E, Snoeck R: Novel Therapeutics for Epstein-Barr Virus. Molecules. 2019; 24(5): pii: E997.

PubMed Abstract | Publisher Full Text | Free Full Text

2. Cohen JI: Epstein-Barr virus infection. N Engl J Med. 2000; 343(7): 481-492. PubMed Abstract | Publisher Full Text

3. Edreis A, Mohamed MA, Mohamed NS, et al: Molecular Detection of Epstein - Barr virus in Nasopharyngeal Carcinoma among Sudanese population. Infect Agent Cancer. 2016; 11: 55

PubMed Abstract | Publisher Full Text | Free Full Text

4. Niedboitek G, Young LS: Epstein-Barr virus persistence and virus-associated tumours. Lancet. 1994; 343(8893): 333-335. PubMed Abstract | Publisher Full Text

5. Benchimol S, Minden M: Virus oncogens and tumor suppressor genes. The basic science of oncology. Edited by: Tanno IFHR. New York: McGraw-Hill, 1998; 77-90.

6. Thomas M, Massimi P, Banks L: HPV-18 E6 inhibits p53 DNA binding activity regardless of the oligomeric state of p53 or the exact p53 recognition sequence. Oncogene. 1996; 13(3): 471-480. PubMed Abstract

7. Eltahir HA, Elhassan AM, Ibrahim ME: Contribution of retinoblastoma LOH and the p53 Arg/Pro polymorphism to cervical cancer. Mol Med Rep. 2012; 6(3): 473-476.

PubMed Abstract | Publisher Full Text | Free Full Text

8. Xu M, Zhang WL, Zhu Q, et al:: Genome-wide profiling of Epstein-Barr virus integration by targeted sequencing in Epstein-Barr virus associated malignancies. Theranostics. 2019; 9(4): 1115-1124.

PubMed Abstract | Publisher Full Text | Free Full Text

9. Jemal A, Bray F, Center MM, et al.: Global cancer statistics. CA Cancer J Clin 2011; 61(2): 69-90.

PubMed Abstract | Publisher Full Text

10. Yahia ZA, Adam AA, Elgizouli M, et al:: Epstein Barr virus: a prime candidate of breast cancer aetiology in Sudanese patients. Infect Agent Cancer. 2014; 9(1): 9 PubMed Abstract | Publisher Full Text | Free Full Text

11. Hennighausen L: Mouse models for breast cancer. Breast Cancer Res. 2000; 2(1): 2-7.

PubMed Abstract | Publisher Full Text | Free Full Text

12. Lawson JS, Heng B: Viruses and breast cancer. Cancers (Basel). 2010; 2(2): 752-772.

PubMed Abstract | Publisher Full Text | Free Full Text

13. Glenn WK, Heng B, Delprado W, et al.: Epstein-Barr virus, human papillomavirus and mouse mammary tumour virus as multiple viruses in breast cancer. PLOS One. 2012; 7(11): e48788.

PubMed Abstract | Publisher Full Text | Free Full Text

14. Saeed ME, Cao J, Fadul B, et al.: A five-year survey of cancer prevalence in Sudan. Anticancer Res. 2016; 36(1): 279-86. PubMed Abstract

15. Hilz $\mathrm{H}$, Wiegers $\mathrm{U}$, Adamietz $\mathrm{P}$ : Stimulation of proteinase $\mathrm{K}$ action by denaturing agents: application to the isolation of nucleic acids and the degradation of 'masked' proteins. Eur J Biochem. 1975; 56(1): 103-8. PubMed Abstract | Publisher Full Text

16. Joseph Sambrook DR: Molecular cloning: a laboratory manual. Cold Spring Harbor: Cold Spring Harbor Laboratory Press; 2001 Reference Source

17. Pikor LA, Enfield KS, Cameron $\mathrm{H}$, et al: DNA extraction from paraffin embedded material for genetic and epigenetic analyses. J Vis Exp. 2011; 49: pii: 2763. PubMed Abstract | Publisher Full Text | Free Full Text

18. Rowa H: Replication Data for: EBV and Breast cancer Data among Sudanese patients. 2019. Harvard Dataverse, V2, UNF:6:rsC2x2VWcC9lyZzuBmOkHg== [fileUNF]. https://www.doi.org/10.7910/DVN/94YOCV

19. Ibrahim T, Mercatali L, Amadori D: A new emergency in oncology: Bone metastases in breast cancer patients (Review). Oncol Lett. 2013; 6(2): 306-310. PubMed Abstract | Publisher Full Text | Free Full Text

20. Yousef EM, Tahir MR, St-Pierre $Y$, et al.: MMP-9 expression varies according to molecular subtypes of breast cancer. BMC Cancer. 2014; 14: 609. PubMed Abstract | Publisher Full Text | Free Full Text

21. Lynch JB, Omar A: Cancer in the Sudan. Sudan Med J. 1963; 2: 29-37.

22. Elamin A, Ibrahim ME, Abuidris D, et al:: Part I: cancer in Sudan-burden, distribution, and trends breast, gynecological, and prostate cancers. Cancer Med. 2015; 4(3): 447-456. PubMed Abstract | Publisher Full Text | Free Full Text

23. Saeed IE, Weng HY, Mohamed KH, et al.: Cancer incidence in Khartoum, Sudan: first results from the Cancer Registry, 2009-2010. Cancer med. 2014; 3(4): 1075-84.

PubMed Abstract | Publisher Full Text | Free Full Text

24. Labrecque LG, Barnes DM, Fentiman IS, et al.: Epstein-Barr virus in epithelial cell tumors: a breast cancer study. Cancer Res. 1995; 55(1): 39-45. PubMed Abstract

25. Arbach $\mathrm{H}$, Viglasky V, Lefeu $\mathrm{F}$, et al.: Epstein-Barr virus (EBV) genome and expression in breast cancer tissue: effect of EBV infection of breast cance cells on resistance to paclitaxel (Taxol). J Virol. 2006; 80(2): 845-853. PubMed Abstract | Publisher Full Text | Free Full Text

26. Mazouni C, Fina F, Romain S, et al:: Epstein-Barr virus as a marker of biological aggressiveness in breast cancer. Br J Cancer. 2011; 104(2): 332-337. PubMed Abstract | Publisher Full Text | Free Full Text

27. Bonnet M, Guinebretiere JM, Kremmer E, et al.: Detection of Epstein-Barr virus in invasive breast cancers. J Natl Cancer Inst. 1999; 91(16): 1376-1381. PubMed Abstract | Publisher Full Text

28. Fina F, Romain S, Ouafik L, et al: Frequency and genome load of Epstein-Bar virus in $\mathbf{5 0 9}$ breast cancers from different geographical areas. $\mathrm{Br} \mathrm{J}$ Cancer. 2001; 84(6): 783-790.

PubMed Abstract | Publisher Full Text | Free Full Text

29. McCall SA, Lichy JH, Bijwaard KE, et al:: Epstein-Barr virus detection in ductal carcinoma of the breast. J Natl Cancer Inst. 2001 ; 93(2): 148-150. PubMed Abstract | Publisher Full Text

30. Grinstein S, Preciado MV, Gattuso P, et al.: Demonstration of Epstein-Barr virus 
in carcinomas of various sites. Cancer Res. 2002; 62(17): 4876-4878. PubMed Abstract

31. Xue SA, Lampert IA, Haldane JS, et al.: Epstein-Barr virus gene expression in human breast cancer: protagonist or passenger? Br J Cancer. 2003; 89(1): 113-119.

PubMed Abstract | Publisher Full Text | Free Full Text

32. Thorne LB, Ryan JL, Elmore SH, et al: Real-time PCR measures Epstein-Barr Virus DNA in archival breast adenocarcinomas. Diagn Mol Pathol. 2005; 14(1): $29-33$.

PubMed Abstract | Publisher Full Text

33. Perkins RS, Sahm K, Marando C et al:: Analysis of Epstein-Barr virus reservoirs in paired blood and breast cancer primary biopsy specimens by real time PCR. Breast Cancer Res. 2006; 8(6): R70.

PubMed Abstract | Publisher Full Text | Free Full Text

34. Glaser SL, Ambinder RF, DiGiuseppe JA, et al:: Absence of Epstein-Barr virus EBER-1 transcripts in an epidemiologically diverse group of breast cancers. Int J Cancer. 1998; 75(4): 555-558.

PubMed Abstract | Publisher Full Text

35. Dadmanesh F, Peterse JL, Sapino A, et al:: Lymphoepithelioma-like carcinoma of the breast: lack of evidence of Epstein-Barr virus infection. Histopathology. 2001; 38(1): 54-61.

PubMed Abstract | Publisher Full Text

36. Deshpande CG, Badve S, Kidwai N, et al.: Lack of expression of the Epstein-
Barr Virus (EBV) gene products, EBERs, EBNA1, LMP1, and LMP2A, in breast cancer cells. Lab Invest. 2002; 82(9): 1193-1199. PubMed Abstract | Publisher Full Text

37. Murray PG, Lissauer D, Junying J, et al:: Reactivity with A monoclonal antibody to Epstein-Barr virus (EBV) nuclear antigen 1 defines a subset of aggressive breast cancers in the absence of the EBV genome. Cancer Res. 2003; 63(9): 2338-2343.

PubMed Abstract

38. Herrmann K, Niedobitek G: Lack of evidence for an association of Epstein-Barr virus infection with breast carcinoma. Breast Cancer Res. 2003; 5(1): R13-R17. PubMed Abstract | Publisher Full Text | Free Full Text

39. $\mathrm{Hu} \mathrm{H}$, Luo ML, Desmedt C, et al.: Epstein-Barr Virus Infection of Mammary Epithelial Cells Promotes Malignant Transformation. EBioMedicine. 2016; 9 : 148-160.

PubMed Abstract | Publisher Full Text | Free Full Text

40. Mohammadizadeh F, Zarean M, Abbasi M: Association of Epstein-Barr virus with invasive breast carcinoma and its impact on well-known clinicopathologic parameters in Iranian women. Adv Biomed Res. 2014; 3: 141.

PubMed Abstract | Free Full Text

41. Kadivar M, Monabati A, Joulaee A, et al.: Epstein-Barr virus and breast cancer: lack of evidence for an association in Iranian women. Pathol Oncol Res. 2011; 17(3): 489-92.

PubMed Abstract | Publisher Full Text 


\section{Open Peer Review}

\section{Current Peer Review Status: $\mathrm{X} X$}

\section{Version 1}

Reviewer Report 04 February 2020

https://doi.org/10.5256/f1000research.21291.r59388

(C) 2020 Lawson J. This is an open access peer review report distributed under the terms of the Creative Commons Attribution License, which permits unrestricted use, distribution, and reproduction in any medium, provided the original work is properly cited.

James Lawson

School of Biotechnology and Biomolecular Sciences, University of New South Wales, Sydney, Australia

Unfortunately the manuscript and the study have serious flaws.

The most important flaw is the lack of recognition of infiltrating lymphocytes in breast cancer specimens. These lymphocytes can be Epstein Barr positive and give false positive outcomes of PCR based studies.

This issue has long been recognised by others and is repeatedly referred to in the literature This problem can be overcome in several ways as published.

In addition the results of the controls are not reported properly? See Table 2 . This table does not make sense. This problem has been commented by a previous reviewer.

I am sorry but this project is not of sufficient quality to deserve indexing.

Is the work clearly and accurately presented and does it cite the current literature? No

Is the study design appropriate and is the work technically sound? No

Are sufficient details of methods and analysis provided to allow replication by others? No

If applicable, is the statistical analysis and its interpretation appropriate? Partly 
Are all the source data underlying the results available to ensure full reproducibility? No

Are the conclusions drawn adequately supported by the results?

No

Competing Interests: No competing interests were disclosed.

I confirm that I have read this submission and believe that I have an appropriate level of expertise to state that I do not consider it to be of an acceptable scientific standard, for reasons outlined above.

Reviewer Report 16 December 2019

https://doi.org/10.5256/f1000research.21291.r52048

(C) 2019 Mohammed S. This is an open access peer review report distributed under the terms of the Creative Commons Attribution License, which permits unrestricted use, distribution, and reproduction in any medium, provided the original work is properly cited.

\section{Sulma Ibrahim Mohammed}

Department of Comparative Pathobiology, Purdue University Center for Cancer Research, Purdue University, West Lafayette, IN, USA

In the Abstract: Method: the age of the control group is far younger compared to patients (37 vs 50).

Result section - control group - only the histological type is provided. It should show the virus presence in tissue of patients with breast cancer compared to control without cancer - that does not make sense.

In the Methods: how are the tissues fixed and embedded in blocks and how long?

Results: Table 1 - describe only patients - why not control as well?

Table 2: does not make sense and is not clear.

In results sections: last paragraph state that "In the control group, EBV was detected in 101/115 $(87.8 \%)$ and only $14 / 115(12.2 \%)$ tested negative for the presence of the virus" that means the virus is present in the majority of control samples - which render the conclusion wrong.

Fig 1 is not necessary unless control samples are included as well.

Discussion: the author should discuss their results and not cite the literature (this was done in the introduction) - they should discuss what their results mean and what was the importance of looking at the stage, age and virus presence. 
Is the work clearly and accurately presented and does it cite the current literature? Yes

Is the study design appropriate and is the work technically sound?

Partly

Are sufficient details of methods and analysis provided to allow replication by others? Yes

If applicable, is the statistical analysis and its interpretation appropriate?

Partly

Are all the source data underlying the results available to ensure full reproducibility? Partly

Are the conclusions drawn adequately supported by the results?

No

Competing Interests: No competing interests were disclosed.

Reviewer Expertise: Cancer biology sp breast cancer.

I confirm that I have read this submission and believe that I have an appropriate level of expertise to state that I do not consider it to be of an acceptable scientific standard, for reasons outlined above.

The benefits of publishing with F1000Research:

- Your article is published within days, with no editorial bias

- You can publish traditional articles, null/negative results, case reports, data notes and more

- The peer review process is transparent and collaborative

- Your article is indexed in PubMed after passing peer review

- Dedicated customer support at every stage

For pre-submission enquiries, contact research@f1000.com 